\title{
ANALIZA SADRŽAJA REVIZORSKIH IZVEŠTAJA SA ASPEKTA PROCENE VREDNOSTI STALNE IMOVINE KAO ZNAČAJNOG FAKTORA USPEŠNOSTI POSLOVANJA
}

\section{Milena Bokić}

Univerzitet Singidunum, Beograd, Srbija

\begin{abstract}
Apstrakt:
Finansijski izveštaji predstavljaju osnovu procene trenutne pozicije na tržištu i donošenja poslovnih odluka. Shodno tome finansijski izveštaji i njihova kontrola i formiranje mišljenja od strane revizora treba da pruže kvalitetne informacije koje će doprineti ispravnim odlukama. Cilj ovog rada je sagledavanje objavljenih mišljenja revizora o proceni vrednosti stalne imovine privrednih društava. Poseban fokus je stavljen na ovu poziciju iz razloga što će, u zavisnosti od usvojenih računovodstvenih politika, vrednovanje stalne imovine imati uticaja, kako na sam imovinski položaj, tako i na finansijski rezultat privrednog društva. Kako bi ispunili cilj rada, slučajnim izborom odabrano je 90 javnih društava koja posluju na Beogradskoj berzi. Prikupljeni su njihovi finansijski izveštaji i analiziran je sadržaj mišljenja revizora.
\end{abstract}

Ključne reči:

finansijski izveštaji, stalna imovina, revizorsko mišljenje.
Korespondencija:

Milena Bokić

e-mail:

mbokic@singidunum.ac.rs
UVOD

Računovodstvo predstavlja osnovu pružanja informacija za olakšano donošenje poslovnih odluka i upravljanje privrednim društvom. Usvajanjem Međunarodnih računovodstvenih standarda (MRS) i Međunarodnih standarda finansijskog izveštavanja (MSFI) obezbeđena je standardizacija i uz interne računovodstvene regulative definisano prikazivanje poslovnih promena na način da se olakša razumevanje računovodstvenih informacija. Stalna sredstva predstavljaju sredstva koja imaju vek upotrebe duži od godinu dana, koja su nabavljena radi korišćenja u poslovanju i koja se ne drže radi prodaje kupcima, već se očekuje da će doneti koristi privrednom društvu u dužem vremenskom periodu od godinu dana (Krstić et al., 2010). Stalna imovina se deli na nematerijalna sredstva, osnovna sredstva i dugoročna finansijska ulaganja. Svaki od ovih aspekata stalne imovine je definisan i regulisan kroz računovodstvene politike određenog privrednog društva. Pri sastavljanju finansijskih izveštaja u zavisnosti od materijalnog značaja bilansne pozicije, ove procene vrednosti će uticati na položaj privrednog društva. Računovodstvene politike se po pravilu definišu skoro za svaku bilansu poziciju, a njihov sadržaj je određen profesionalnom regulativom. U ovom radu akcenat će biti stavljen na sagledavanje procene stalne imovine na osnovu usvojenih standarda i politika, obzirom da to predstavlja značajnu stavku u celokupnom finansijskom izveštavanju. Da li je procena stalne imovine vršena u skladu sa propisanom politikom privrednog društva možemo zaključiti na osnovu sadržaja revizorskih izveštaja, gde smo izvršili analizu iznetih mišljenja sa aspekta ispravnosti prikazivanja pozicija stalne imovine. Cilj revizije je da revizor iznese mišljenje o tome da li su finansijski izveštaji sastavljeni u skladu sa propisanim standardima. Time se daje potvrda vlasnicima da su ostvarili efekte koji odgovaraju stanju u finansijskim izveštajima, a eksternim subjektima daju uverenja da je prikazan realni odraz stanja o poslovanju privrednog društva, čime se povećava njegov kredibilitet (Stanišić, 2013). 


\section{PROCENA VREDNOSTI STALNE IMOVINE}

Usvajanjem MSFI, privredna društva su u obavezi da ih poštuju i primenjuju. Na koji način i kojom metodom ćemo vrednovati stalnu imovinu zavisi od usvojenih računovodstvenih politika, koja moraju biti u skladu sa navedenim standardima. Kada je sredstvo ispunilo propisane uslove da bude priznato kao stalna imovina vrši se njegovo vrednovanje. Ovaj tip vrednovanja predstavlja početno vrednovanje, koje se vrši na dan uvođenja sredstva u finansijsko izveštavanje. Izbor metode naknadnog vrednovanja sredstava može dosta uticati na finansijski rezultat privrednog društva. Prema MRS 16 - Nekretnine, postrojenja i oprema, za vrednovanje stalne imovine nakon njihovog početnog priznavanja postoje dva postupka: model troška nabavke - nabavnu vrednost ili cenu koštanja umanjujemo za iznos amortizacije i gubitke zbog obezvređenja i model revalorizacije - nakon početnog priznavanja sredstava, na datum bilansa se vrednuju po utvrđenoj fer vrednosti (Petrović, 2013).

Već smo ukazali na značaj stalne imovine kao bilansne pozicije, te i sam pravilan izbor njenog naknadnog vrednovanja je od velikog značaja za privredno društvo. Naročito se ovaj uticaj ogleda u kapitalno intenzivnim privrednim društvima. Pri upotrebi modela troška nabavke i utvrđivanju primenjene metode amortizacije privredno društvo prvo treba da krene od toga da li se neko sredstvo amortizuje ili ne. Ukoliko se vrši amortizacija, prema propisanim standardima, privredno društvo se može odlučiti za jedan od tri najčešće korišćena metoda: linearni, degresivni ili funkcionalni metod. Definisanjem računovodstvenih politika, privredno društvo samo odlučuje koji metod amortizacije je pogodan za primenu sa potrebe finansijskog izveštavanja ${ }^{1}$. Takođe, standard ne propisuje amortizacione stope, već u skladu sa intenzitetom i vremenom korišćenja stalnih sredstava, privredno društvo samo obračunava stope.

Linearni metod amortizacije predstavlja vremensku amortizaciju i najjednostavniji oblik obračuna amortizacije. Osnova ovog metoda je pretpostavka ravnomernog trošenja sredstava tokom veka korišćenja. Prednosti ovog metoda su da je jednostavan za obračun, i da se može primeniti na sva sredstva. Izbor metoda amortizacije radi privredno društvo, ali ukoliko ne može da utvrdi ekonomske koristi koje će imati, primenjuje se svakako linearni metod amortizacije. I pored nedostataka da ne uzima u obzir troškove održavanja, moguću promenu intenziteta korišćenja sredstva, i dalje predstavlja najzastupljeniji metod. Degresivni metod uklanja prethodni nedostatak, jer uzima u obzir promenu intenziteta korišćenja osnovnog sredstva. Spada u vremensku amortizaciju, ali uzima u obzir odnos prihoda i troškova nastalih korišćenjem sredstva.

1 Izveštavanje za potrebe obračuna poreza se mora uskladiti sa Zakonom o porezu na dobit pravnih lica, koji može zahtevati drugačiju metodu amortizacije i amortizacionu stopu u zavisnosti od tipa sredstva.
Tako polazi od pretpostavke da novija sredstva više doprinose stvaranju prihoda i da smanjenje ide s godinama korišćenja. Funkcionalni metod se zasniva na očekivanom korišćenju sredstava. Ovim metodom se takođe postiže visok stepen korelacije između prihoda i troškova, jer se smatra da ostvareni prihodi su zavisni od obima pruženih usluga korišćenjem sredstva. Kod izbora metode, privredno društvo može da primeni različite metode na sredstvima koje poseduje, kao i da u toku poslovanja preispituje već primenjene metode i ukoliko uslovi poslovanja to zahtevaju, promeni metod obračuna. Kratkoročno gledano, izbor metoda amortizacije utiče na finansijski rezultat, jer posmatrajući svaku godinu ponaosob rezultat može biti različit u zavisnosti od primenjene amortizacije. Međutim, u dugom roku, kada bismo sagledali prosek, videli bismo da nema uticaja na finansijski rezultat, što dovodi do zaključka da izborom metode možemo donekle manipulisati iskazivanje visine finansijskog rezultata.

Metod nabavne vrednosti je češće korišćeni metod naknadne procene stalnih sredstava. Jednostavniji je za korišćenje, podaci su tačni i provereni. Međutim, svrha finansijskih izveštaja je da pruži istinite, precizne i tačne informacije i pravu sliku o poslovanju privrednog društva. Kako se vrlo često knjigovodstvena vrednost razlikuje od tržišne vrednosti, sve više se zagovara primena metode fer vrednosti. Ovaj metod se primenjuje nad sredstvima gde dolazi do česte promene tržišne vrednosti i gde se ta tržišna vrednost može sa sigurnošću utvrditi ili gde dolazi do česte promene vrednosti nacionalne valute. Revalorizacija se može raditi na bilo koji datum u toku obračunskog perioda. Na kraju obračunskog perioda potrebno je obračunati amortizaciju za sredstva od dana revalorizacije do kraja obračunskog perioda. Ukoliko knjigovodstvene vrednosti značajnije odstupaju od fer vrednosti, potrebno je uraditi revalorizaciju i na datum bilansa (Petrović, 2013). I pored transparentnijeg prikazivanja vrednosti sredstava, privredna društva se češće odlučuju za metod nabavne vrednosti, jer postoji mogućnost negativnog uticaja na finansijski rezultat primenom metode fer vrednosti, što im svakako ne ide u prilog.

\section{METODOLOGIJA I REZULTATI ISTRAŽIVANJA}

Kako bismo dobili odgovor na postavljena pitanja o adekvatnoj proceni vrednosti stalne imovine, sproveli smo istraživanje na uzorku od 90 pravnih lica. Obuhvaćena su mala, srednja i velika pravna lica koja posluju na teritoriji Republike Srbije i registrovana su kod Agencije za privredne registre. Ova pravna lica imaju obavezu sastavljanja i podnošenja finansijskih izveštaja, koji su preuzeti za svrhe istraživanja sa sajta Agencije za privredne registre. Preuzet je i analiziran sadržaj revizorskih izveštaja sa finansijskim izveštajima koji su bili predmet revizije za izveštajni period 2015. godine. Na osnovu selektovanog uzorka i dostupnih izveštaja, izvršena je analiza procene revizora o ispravnosti korišćenih metod vrednovanja stalnih sredstava. 
Tabela 1. Mišljenje revizora o vrednovanju stalne imovine

\begin{tabular}{cccccc}
\hline & \multicolumn{3}{c}{ Mišljenje revizora o stalnoj imovini } & Revizija od strane \\
\cline { 2 - 6 } $\begin{array}{c}\text { Ukupan broj uzorkova- } \\
\text { nih privrednih društava }\end{array}$ & $\begin{array}{c}\text { Pozi- } \\
\text { tivno } \\
\text { mišljenje }\end{array}$ & $\begin{array}{c}\text { Modifikovano mišljenje } \\
\text { u kojem se ne pominje } \\
\text { procena stalne imovine }\end{array}$ & $\begin{array}{c}\text { Modifikovano mišljenje } \\
\text { u kojem se pominje pro- } \\
\text { cena vrednosti imovine }\end{array}$ & Big Four & Ne pripada Big \\
Four
\end{tabular}

Izvor: podaci autora

Od ukupnog uzorkovanog broja, 35 pravnih lica na osnovu pregledanih finansijskih izveštaja dobilo je pozitivno mišljenje revizora. Za preostalih 55 revizori su dali mišljenje s rezervom, negativno ili samo skretanje pažnje. Od toga, za 35 privrednih društava dato je modifikovano mišljenje vezano za procenu stalne imovine. Revizori su izneli mišljenje da u najvećem broju uzoraka nije izvršena naknadna procena vrednosti imovine. U slučajevima gde jeste, nisu bile obelodanjene sve informacije kako bi se izneo zaključak da li je procena izvršena adekvatno. Osnovu za iznošenje negativnog mišljenja i mišljenja s rezervom, u manjem broju slučajeva, činio je obračun amortizacije. Revizori su kao zamerku na obračun amortizacije izneli da je u pojedinim slučajevima došlo do potcenjivanja imovine, da treba ponovo preračunati amortizacionu stopu, i u jednom slučaju da je imovina već u potpunosti amortizovana, a da se i dalje evidentira. Kao nedostatak i skretanje pažnje navedeno je da su pravna lica koristila metod nabavke, a pogodniji je bio metod revalorizacije, čije smo prednosti već naveli. U delu skretanja pažnje, takođe, su navođene hipoteke koje postoje na nepokretnostima pravnih lica.

Pored analize revizorskih izveštaja, uzeto je u obzir i da li je reviziju vršila neka od kompanija koje pripadaju „velikoj četvorci“. U našem uzorku za 7 pravnih lica je urađena revizija od strane neke od kompanija: Deloitte, KPMG, Ernst\&Young, PwC, koje pripadaju navedenoj grupaciji. Izdvajaju se kao posebna grupa jer uzimaju najveće učešće na našem tržištu i posluju u većini država sveta. Karakteriše ih veliki broj domaćih i stranih stručnjaka, dug vek poslovanja, čime opravdavaju svoju reputaciju i poziciju na našem tržištu. Kvalitet njihovih revizorskih izveštaja se ne dovodi u pitanje, i to je jedan od razloga zašto smo sagledali i ovaj aspekt. U preostaloj grupi revizorskih kuća, nismo vršili izdvajanje onih koji predstavljaju „malu četvorku“ do koje su istraživanjem došli u radu Stanišić et al. (2015). Istraživanje je sprovedeno na uzorku od 10.555 revizijskih izveštaja i izdvojena je „mala četvorka" revizorskih kuća koje se mogu izdvojiti kao posebna grupacija, i obuhvata: Privredni Savetnik, Stanišić Audit, Vinčić i Savica. U nekom daljem istraživanju i ova podela može biti uzeta u obzir kao značajna za pouzdanost revizijskih izveštaja.

\section{ZAKLJUČAK}

Zakonom o računovodstvu u našoj državi usvojeni su Međunarodni računovodstveni standardi/ Međunarodni standardi finansijskog izveštavanja koji propisuju pravila evidentiranja svih bilansnih pozicija, ali pružaju mogućnost izbora i primene u skladu sa specifičnostima delatnosti i strategije poslovanja. Ovo sa druge strane daje slobodu menadžmentu u izboru načina procene bilansnih pozicija i u okviru njih i stalne imovine. Izborom različitih metoda procene vrednosti stalne imovine dolazimo do zaključka da njihova primena može imati značajne implikacije na poslovni rezultat privrednog društva, naročito u kratkom roku. Iz tog razloga je potrebno da finansijski izveštaji podležu reviziji kako bi se utvrdile i otklonile eventualne nepravilnosti u primeni računovodstvenih politika. U istraživanju koje smo sproveli gde je obuhvaćeno 90 pravnih lica, u 35 slučajeva revizori su dali modifikovano mišljenje o primenjenim metodama procene vrednosti stalne imovine. Kako smo obrazložili u rezultatima istraživanja u najvećem broju slučajeva je bilo zamerki u obelodanjivanju svih informacija, kako bi se izneo zaključak $o$ ispravnosti procenjene vrednosti. To nam pokazuje da $u$ određenom broju slučajeva, možemo uzeti s rezervom da je došlo do određenih primena računovodstvenih politika, kako bi se pokazao što bolji finansijski rezultat privrednog društva. Međutim, uticaj na rezultat može biti u kratkom roku. Kompletnija slika procene vrednosti stalne imovine može biti dobijena analizom u više sukcesivnih perioda. Obzirom da smo u istraživanju analizirali samo izveštaje iz 2015. godine, u nekom daljem istraživanju bilo bi poželjno uključiti više obračunskih perioda.

\section{LITERATURA}

Krstić, J., Jezdimirović, M., \& Đukić,T. (2010). Finansijsko računovodstvo. Niš: Ekonomski fakultet.

Petrović, Z. (2013). Finansijsko izveštavanje. Beograd: Univerzitet Singidunum.

Stanišić, M. (2013). Revizija. Beograd: Univerzitet Singidunum.

Stanišić, N., Mizdraković, V., Radojević, T., \& Stanić, N. (2015). Defining second-tier audit firms in Serbia: In search of the Small four. The European Journal of Applied Economics, 12(2), 35-43. doi:10.5937/ejae12-9214 


\section{ANALYSIS OF THE CONTENTS OF AUDIT REPORTS FROM THE ASPECT OF THE FIXED ASSETS ASSESSMENT AS A SIGNIFICANT FACTOR OF BUSINESS PERFORMANCE}

\section{Abstract:}

Financial statements present the basis of the assessment of the current position in the market and bringing business decisions. Consequently, the financial statements, their control and the formation of auditor's opinion should provide quality information that will help bringing right decisions. The aim of this paper is an overview of published auditor's opinions on the assessment of the value of fixed assets of business entities. A focus is put on this position since the evaluation of fixed assets will have an impact on both financial status and financial results of the company depending on the adopted accounting policies. In order to reach the aim of the paper, 90 public companies operating on the Belgrade Stock Exchange have been randomly selected. Their financial statements have been collected and the content of the auditor opinions has been analyzed.

\section{Keywords:}

financial statements,

fixed assets,

audit opinion. 